\title{
Production of specific glycosidase activities by Streptococcus intermedius strain UNS35 grown in the presence of mucin
}

\author{
K. A. HOMER, R. A. WHILEY* and D. BEIGHTON \\ Oral Microbiology, Royal College of Surgeons Department of Dental Sciences, Faculty of Clinical Dentistry, King's \\ College School of Medicine and Dentistry, Caldecot Road, Denmark Hill, London SE5 9RW and *Department of \\ Oral Microbiology, London Hospital Medical College, Turner Street, Whitechapel, London E1 2AD
}

\begin{abstract}
Summary. An isolate of Streptococcus intermedius from a brain abscess showed neuraminidase (sialidase), $\beta$-D-galactosidase, $\mathrm{N}$-acetyl- $\beta$-D-glucosaminidase and $\mathrm{N}$-acetyl- $\beta$-D-galactosaminidase activities. The optimal $\mathrm{pH}$ values of these enzymes were $5 \cdot 5-6 \cdot 0,5 \cdot 5-6 \cdot 0$, $5 \cdot 0-5 \cdot 5$ and $5 \cdot 0-5 \cdot 5$, respectively. The $\mathrm{k}_{\mathrm{m}}$ of the enzymes varied according to whether the type of substrate was chromogenic or fluorogenic; sialidase was most active at the lowest substrate concentrations, with a $\mathrm{k}_{\mathrm{m}}$ of $0.01 \mathrm{~mm}$. In semi-defined medium, with porcine gastric mucin - a model glycoprotein - as the sole source of fermentable carbohydrate, levels of the glycosidases were significantly increased. Addition of glucose to the mucin-containing medium, or growth of cells in media supplemented with glucose alone, repressed glycosidic activities and the majority of these were cell-associated. S. intermedius cells from cultures grown with mucin were able, simultaneously, to transport via sugar: phosphoenolpyruvate phosphotransferase (PTS) systems, monosaccharides which are constituents of carbohydrate side chains of glycoproteins. These cells also possessed significant levels of neuraminate-pyruvate lyase, involved in the intracellular catabolism of neuraminic acid; this was absent from cells grown with glucose. These mechanisms, collectively, may facilitate the persistence and growth of $S$. intermedius in vivo.
\end{abstract}

\section{Introduction}

The "Streptococcus milleri group" (SMG) are members of the normal oral, urogenital and gastrointestinal flora and are isolated frequently from a wide range of clinical conditions. ${ }^{1-4}$ Recent taxonomic studies have indicated that the SMG is composed of three distinct species: $S$. anginosus, $S$. constellatus and $S$. intermedius. ${ }^{5}$ Of these, $S$. intermedius is particularly associated with deep-seated, purulent abscesses of the brain and liver. ${ }^{6,7} S$. intermedius strains produce glycosaminoglycan-depolymerising activities, including hyaluronidase and chondroitin sulphate depolymerase, ${ }^{8-10}$ and glycosidic enzyme activities including $\beta$-D-galactosidase, $\mathrm{N}$-acetyl- $\beta$-D-glucosaminidase, $\mathrm{N}$ acetyl- $\beta$-D-galactosaminidase and neuraminidase (sialidase). ${ }^{7,11}$ Collectively, these activities may enable $S$. intermedius to degrade human tissue constituents and facilitate the growth of $S$. intermedius in vivo, and contribute to its pathogenicity.

In this investigation, the specific glycosidase ac- tivities of $S$. intermedius strain UNS35, isolated from a brain abscess, were partially characterised and the influence of a model glycoprotein, porcine gastric mucin, ${ }^{12-14}$ on their production was studied. The ability of $S$. intermedius to transport glycoproteinderived carbohydrates via sugar:phosphoenolpyruvate phosphotransferase (PTS) systems was also investigated to determine the potential of $S$. intermedius to transport glycoprotein-derived monosaccharides.

\section{Materials and methods}

\section{Growth and maintenance of S. intermedius}

Stock cultures of $S$. intermedius strain UNS35 were stored in cryostat tubes (Gibco, Paisley) containing Brain Heart Infusion Broth (BHI; Unipath Ltd, Basingstoke, Hampshire) and glycerol $50 \% \mathrm{v} / \mathrm{v}$ at $-70^{\circ} \mathrm{C}$. Bacteria were subcultured routinely on to Fastidious Anaerobe Agar (FAA; Lab M, Salford, Lancs) containing horse blood $5 \% \mathrm{v} / \mathrm{v}$, and incubated at $37^{\circ} \mathrm{C}$ for 2 days in an anaerobic cabinet (Don 
Whitley, Shipley, West Yorks) with an atmosphere of $\mathrm{N}_{2} 80 \%, \mathrm{CO}_{2} 10 \%, \mathrm{H}_{2} 10 \%$.

\section{Preparation of cell suspensions and crude cell-free} extracts

Cell suspensions $\left(\mathrm{OD}_{620}=2 \cdot 0\right)$ were prepared from 2-day-old FAA cultures by suspending cells in ice-cold $50 \mathrm{~mm}$ Tris- $\mathrm{HCl}$ buffer, $\mathrm{pH} 7 \cdot 5$ (Tris buffer). Cell-free extracts were prepared by dispensing $2-\mathrm{ml}$ volumes into 5-ml glass screw-capped bottles and, with $0.5 \mathrm{~g}$ of glass Ballotini (Grade 12, BDH, Poole, Dorset), shaking them in a Mickle disintegrator (The Mickle Laboratory Engineering Company Ltd, Gomshall, Surrey) for $10 \mathrm{~min}$ at $4^{\circ} \mathrm{C}$. Cell debris was removed by centrifugation (MSE Microfuge; $13000 \mathrm{rpm}, 5 \mathrm{~min}$, $4^{\circ} \mathrm{C}$ ) and supernates were used in glycosidase assays.

\section{Protein estimation}

Protein concentrations of cell suspensions and extracts were determined with the Coomassie Blue dye-binding assay by means of a commercial kit (Kit No. 610-A; Sigma); all volumes were reduced proportionately. Samples $(1.25 \mathrm{ml})$ of dye reagent were dispensed into disposable cuvettes (Elkay Laboratory Products, UK, Ltd, Basingstoke, Hampshire) and $25 \mu \mathrm{l}$ of sample were added. After mixing thoroughly, the absorbance of the dye-sample mixture was determined at $595 \mathrm{~nm}$. Protein concentrations were calculated by comparison with a curve constructed with bovine serum albumin (Sigma) prepared in Tris buffer.

\section{Preparation of glycosidase substrates}

Glycosidic activities were measured with chromogenic ( $p$-nitrophenol-linked; pNP) and fluorogenic (4methylumbelliferyl-linked; 4MU) substrates. The chromogenic substrates pNP-N-acetyl- $\beta$-D-galactosaminide, $\mathrm{pNP}-\mathrm{N}$-acetyl- $\beta$-D-glucosaminide, $\mathrm{pNP}-\beta$ mannoside, $\mathrm{pNP}-\alpha$-mannoside and $\mathrm{pNP}-\beta$-D-galactoside were prepared at $10 \mathrm{~mm}$. The fluorogenic substrates $4 \mathrm{MU}-\mathrm{N}$-acetyl- $\beta$-D-galactosaminide, $4 \mathrm{MU}$ $\mathrm{N}$-acetyl- $\beta$-D-glucosaminide, $4 \mathrm{MU}-\beta$-mannoside, $4 \mathrm{MU}-\alpha$-mannoside, $4 \mathrm{MU}-\beta$-D-galactoside and $2^{\prime}$ (4MU)- $\alpha-\mathrm{D}-\mathrm{N}$-acetylneuraminic acid were prepared at 1 or $10 \mathrm{~mm}$. All substrates were obtained from Sigma and were freshly prepared. Each substrate was dissolved in dimethylsulphoxide (BDH) and then distilled water to give a final dimethyl sulphoxide concentration of $20 \% \mathrm{v} / \mathrm{v}$.

\section{Determination of optimal $\mathrm{pH}$ values}

The range of buffers used at $0 \cdot 2 \mathrm{M}$ comprised: citric acid-trisodium citrate, pH 3.0-6.0; $\mathrm{NaH}_{2} \mathrm{PO}_{4}$ -

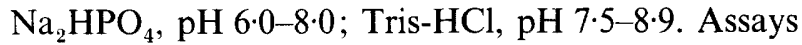
utilising chromogenic substrates contained: $35 \mu \mathrm{l}$ of $0.2 \mathrm{M}$ buffer; $10 \mu \mathrm{l}$ of $10 \mathrm{~mm}$ pNP-linked substrate; $10 \mu \mathrm{l}$ of cell suspension or crude cell-free extract; and distilled water to a final volume of $100 \mu$ l. Assays utilising fluorogenic substrates consisted of : $35 \mu$ of
$0 \cdot 2 \mathrm{M}$ buffer; $25 \mu \mathrm{l}$ of $1 \mathrm{~mm} 4 \mathrm{MU}-$ linked substrate; $10 \mu \mathrm{l}$ of cell suspension or crude cell-free extract; and distilled water to $100 \mu \mathrm{l}$. All assays were set up in duplicate in transparent 96-well microtitration trays (ICN-Flow, High Wycombe, Buckinghamshire) and were initiated by the addition of cell suspension or cellfree extract. Control assays contained all assay components except bacterial cell preparations and the total volume of these assays was maintained at $100 \mu \mathrm{l}$ by the addition of an appropriate amount of Tris buffer. Assays were incubated at $37^{\circ} \mathrm{C}$ so that the rate of increase in product formation was linear with respect to time and were terminated by the addition of $100 \mu \mathrm{l}$ of $0.5 \mathrm{M} \mathrm{NaHCO}-\mathrm{Na}_{2} \mathrm{CO}_{3}$, $\mathrm{pH} 10 \cdot 2$.

The release of $\mathrm{pNP}$ was determined at $405 \mathrm{~nm}$ in a 96-well plate-reading spectrophotometer (ICN-Flow), and by comparison with the absorbance of standard concentrations of pNP treated with the $\mathrm{NaHCO}_{3}$ $\mathrm{Na}_{2} \mathrm{CO}_{3}$ buffer. The release of $4 \mathrm{MU}$ was determined in a fluorescence spectrophotometer fitted with a platereading attachment (LS-3B, Perkin-Elmer, Beaconsfield, Herts); excitation and emission wavelengths were $380 \mathrm{~nm}$ and $460 \mathrm{~nm}$, respectively. Concentrations of liberated $4 \mathrm{MU}$ were calculated by comparison of fluorescence values with those obtained from standard concentrations of $4 \mathrm{MU}$ treated with the $\mathrm{NaHCO}_{3}-\mathrm{Na}_{2} \mathrm{CO}_{3}$ buffer.

\section{Determination of Michaelis constants}

The Michaelis constants $\left(\mathrm{k}_{\mathrm{m}}\right)$ for N-acetyl- $\beta$-Dgalactosaminidase, $\mathrm{N}$-acetyl- $\beta$-D-glucosaminidase and $\beta$-D-galactosidase activities were determined with citrate buffer, $\mathrm{pH}$ 5.5. The $\mathrm{k}_{\mathrm{m}}$ for neuraminidase was determined in citrate buffer, $\mathrm{pH} \mathrm{6.0.} \mathrm{Assays} \mathrm{con-}$ tained: $35 \mu \mathrm{l}$ of $0.2 \mathrm{M}$ citrate buffer; $10 \mu \mathrm{l}$ of crude cell-free extract; variable volumes of $10 \mathrm{~mm}$ substrate; and water to a final volume of $100 \mu$ l. Substrates were included up to a final concentration of $5.5 \mathrm{~mm}$ and all assays were set up in duplicate. Control assays were included as before, and all assays were incubated at $37^{\circ} \mathrm{C}$ and terminated by the addition of $100 \mu \mathrm{l}$ of $0.5 \mathrm{M}$ $\mathrm{NaHCO}_{3}-\mathrm{Na}_{2} \mathrm{CO}_{3}$ buffer while the rate of reaction was linear.

\section{Units of enzyme activity}

Glycosidic enzyme activities were expressed as units/mg of protein, where 1 unit was the amount of enzyme required to catalyse the production of $1 \mathrm{nmol}$ of $\mathrm{pNP}$ or $4 \mathrm{MU} / \mathrm{min}$.

\section{Growth of S. intermedius in semi-defined media and induction of glycosidic activities}

Bacteria were grown in a semi-defined medium as described previously, ${ }^{15,16}$ to which either porcine gastric mucin (Sigma; a model glycoprotein) or glucose was added. Mucin was dissolved at $1 \% \mathrm{w} / \mathrm{v}$ in $10 \mathrm{~mm}$ potassium phosphate buffer, $\mathrm{pH} 7.5$, and sterilised by autoclaving at $121^{\circ} \mathrm{C}$ for $15 \mathrm{~min}$. Glucose, in the same buffer, was sterilised by filtration $(0 \cdot 2-\mu \mathrm{m}$ 


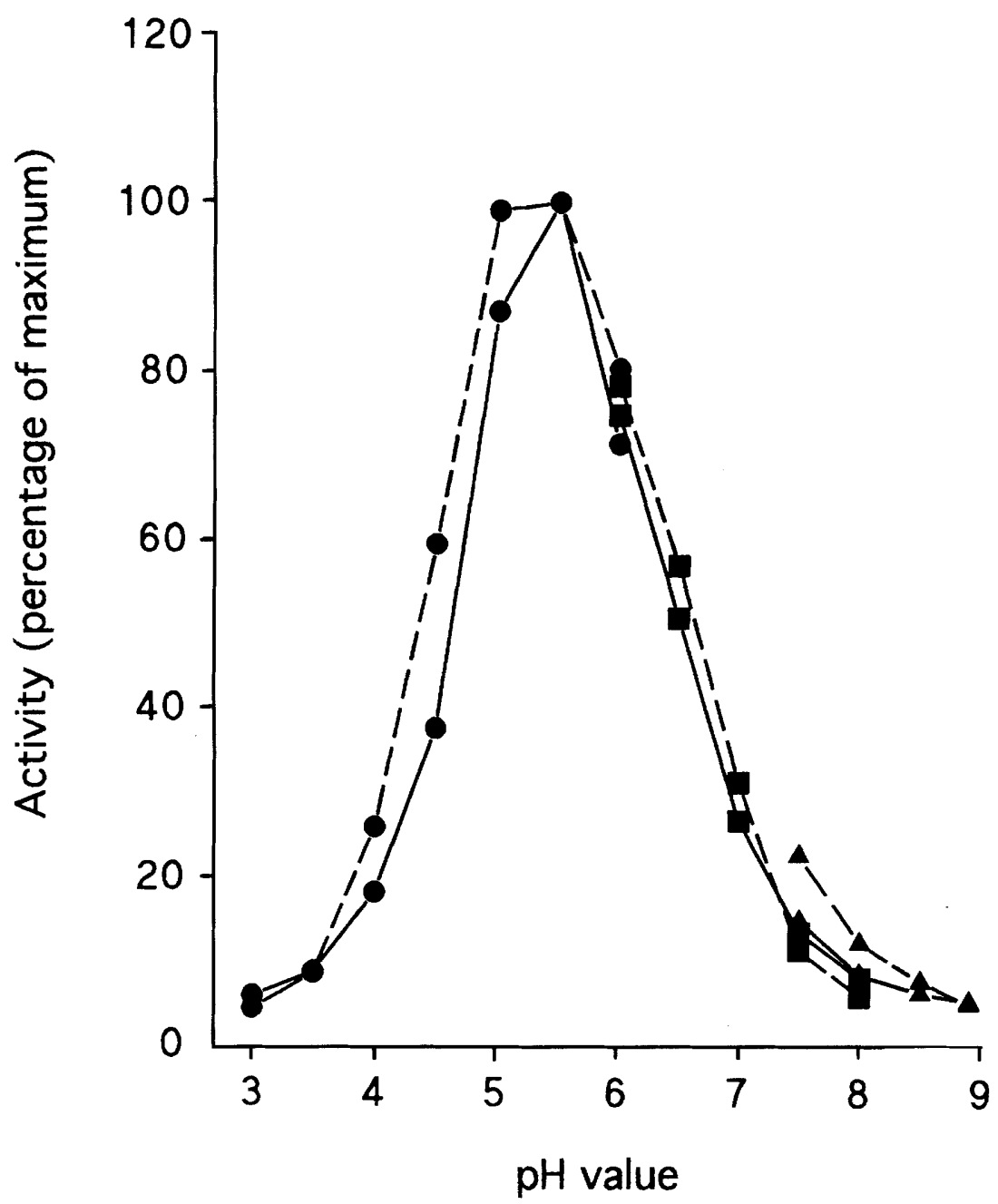

Figure $\mathrm{pH}$ Optimum of $S$. intermedius $\mathrm{N}$-acetyl- $\beta$-D-glucosaminidase in crude cell-free extracts from cultures grown on FAA. Activity is given as a percentage of the maximum for each $\mathrm{N}$-acetyl- $\beta$-D-glucosaminidase substrate (chromogenic or fluorogenic). Buffers: $O$, citrate; sodium phosphate; $\boldsymbol{\Delta}$, Tris-HCl. Substrates: — $\_$chromogenic (pNP-linked); ----_-, fluorogenic (4MU-linked).

pore size filters; Sigma). S. intermedius grown on FAA was inoculated into $20 \mathrm{ml}$ of pre-reduced $\mathrm{BHI}$ and incubated anaerobically at $37^{\circ} \mathrm{C}$ until the late exponential phase; $200-\mu$ l samples were used to inoculate $5-\mathrm{ml}$ volumes of the semi-defined media containing mucin, glucose (at final concentrations of $0.5 \% \mathrm{w} / \mathrm{v}$ and 10 or $50 \mathrm{~mm}$, respectively) or mucin and glucose. Cultures were set up in triplicate and incubated anaerobically at $37^{\circ} \mathrm{C}$ for $24 \mathrm{~h}$. Cells were harvested by centrifugation, washed in $50 \mathrm{~mm}$ sodium phosphate buffer $(\mathrm{pH} \mathrm{7.5)}$ and both culture supernates and cell pellets were stored at $-20^{\circ} \mathrm{C}$. Cells and culture supernates were thawed at ambient temperature and stored on ice. Cell pellets were resuspended in ice-cold sodium phosphate buffer and glycosidic activities were determined with fluorogenic substrates. Assays were performed as described above with substrates added at $0.25 \mathrm{mM}$, except for $2^{\prime}-(4 \mathrm{MU})-\alpha-\mathrm{D}-\mathrm{N}$-acetylneuraminic acid which was added at $25 \mu \mathrm{M}$, and the specific activities were calculated.

\section{Determination of phosphoenolpyruvate: sugar phosphotransferase (PTS) activities}

$S$. intermedius was grown anaerobically for $18 \mathrm{~h}$ in pre-reduced semi-defined medium supplemented with mucin $0.5 \%$ or $10 \mathrm{~mm}$ glucose. Cells were harvested by centrifugation ( $4000 \mathrm{rpm}, 10 \mathrm{~min}$ ), washed by centrifugation in an equal volume of $50 \mathrm{~mm}$ potassium phosphate buffer ( $\mathrm{pH} \mathrm{7.0)}$ and resuspended to give an $\mathrm{OD}_{620}=2 \cdot 0$. Cells were decryptified by adding toluene:acetone $(1: 4) 1 \% \mathrm{v} / \mathrm{v}$ and mixing at maximum speed for $90 \mathrm{~s}$ on a vortex mixer. PTS activities were determined by the method of Slee and Tanzer. ${ }^{17}$ Assays contained: $25 \mathrm{~mm}$ potassium phosphate buffer, $\mathrm{pH} 7 \cdot 0 ; 1 \mathrm{~mm}$ phosphoenolpyruvate; 2 units of lactate dehydrogenase; $0.1 \mathrm{~mm} \mathrm{NADH} ; 1 \mathrm{~mm} \mathrm{MgCl}_{2} ; 10 \mathrm{~mm}$ sodium fluoride; an appropriate volume of decryptified cell suspension; and $10 \mathrm{~mm}$ monosaccharide; in a total volume of $1 \mathrm{ml}$. All monosaccharides were prepared in distilled water; they were glucose, galactose, mannose, fucose, N-acetylglucosamine, $\mathrm{N}$-acetylgalactosamine and, as a negative control, mannitol.

Assay mixtures (without carbohydrate) were prepared in disposable UV-transparent cuvettes (Elkay) and pre-incubated at $37^{\circ} \mathrm{C}$ for $10 \mathrm{~min}$. Reactions were initiated by the addition of monosaccharides and oxidation of NADH was monitored at $340 \mathrm{~nm}$. Each assay was performed in duplicate; distilled water 
replaced the carbohydrate solution in control assays. The number of moles of NADH oxidised in each reaction was calculated by reference to a standard curve and specific activities of PTS systems, as nmol of $\mathrm{NADH}$ oxidised $/ \mathrm{min} / \mathrm{mg}$ of protein, were calculated.

\section{Assay of $\mathrm{N}$-acetylneuraminate-pyruvate lyase activity}

$S$. intermedius was grown in the semi-defined medium supplemented with mucin $0.5 \% \mathrm{w} / \mathrm{v}$ or $10 \mathrm{~mm}$ glucose, washed by centrifugation and stored at $-20^{\circ} \mathrm{C}$. Assays contained: $25 \mathrm{~mm}$ potassium phosphate buffer, $\mathrm{pH} 7 \cdot 0,2$ units of lactate dehydrogenase; $0.1 \mathrm{~mm} \mathrm{NADH}$; an appropriate volume of cell-free extract prepared from the frozen cell pellets; and $10 \mathrm{~mm}$ N-acetylneuraminic acid (Sigma); in a total volume of $1 \mathrm{ml}$. Assays were pre-incubated at $37^{\circ} \mathrm{C}$ for $10 \mathrm{~min}$. Reactions were initiated by the addition of $\mathrm{N}$ acetylneuraminate and the oxidation of NADH was monitored at $340 \mathrm{~nm}$. Control assays contained distilled water in place of $\mathrm{N}$-acetylneuraminic acid and specific activities were expressed as $\mu \mathrm{mol}$ of NADH oxidised $/ \mathrm{min} / \mathrm{mg}$ of protein.

\section{Results}

\section{Optimal $p H$ values of glycosidases}

A typical profile of the relationship between $\mathrm{pH}$ and $\mathrm{N}$-acetyl- $\beta$-D-glucosaminidase activity of cell-free extract is shown in the figure. The $\mathrm{pH}$ profiles for the other glycosidases produced by $S$. intermedius strain UNS35 indicated that the optimal pH value was between 5.0 and 5.5 for both $\mathrm{N}$-acetylglucosaminidase and $\mathrm{N}$-acetylgalactosaminidase and between 5.5 and 6.0 for $\beta$-D-galactosidase and neuraminidase (table I). Optimal $\mathrm{pH}$ values were identical with both chromogenic and fluorogenic substrates and the $\mathrm{pH}$ profiles for whole cells were indistinguishable from those of crude cell-free extracts (data not shown). Each glycoside functioned over a wide $\mathrm{pH}$ range. $\mathrm{N}$-acetylglucosaminidase and $\mathrm{N}$-acetylgalactosaminidase exhibited $>50 \%$ activity over the $\mathrm{pH}$ range $4 \cdot 5-6 \cdot 5, \beta$-Dgalactosidase in the range $\mathrm{pH} 5 \cdot 0-7 \cdot 2$ and neuraminidase in the range $\mathrm{pH} 4 \cdot 8-7 \cdot 1$ (table I). However, the absolute activity of each glycosidase was dependent upon the leaving group of the synthetic substrate (table II). The specific activity of the $\beta$-D-galactosidase enzyme was the highest and that of the neuraminidase the least, irrespective of whether the substrate used was chromogenic or fluorogenic. Activities of $\beta$-Dmannosidase and $\alpha$-D-mannosidase were very low; $<0.1$ units $/ \mathrm{mg}$ of protein were detected with both chromogenic and fluorogenic substrates.

\section{$k_{m}$ Determinations}

The $\mathrm{k}_{\mathrm{m}}$ values varied markedly among glycosidases. Neuraminidase had the greatest affinity for the substrate, as demonstrated by the low value of $k_{m}$, whereas
$\beta$-D-galactosidase had the least, irrespective of the leaving group (table III); $\mathrm{k}_{\mathrm{m}}$ values were consistently lower with fluorogenic substrates.

\section{Induction of glycosidases}

Cultures of S. intermedius grown with mucin exhibited high levels of $\beta$-D-galactosidase, $\mathrm{N}$-acetyl- $\beta$-Dglucosaminidase, $\mathrm{N}$-acetyl- $\beta$-D-galactosaminidase and neuraminidase (sialidase) activities, but no $\beta$ mannosidase or $\alpha$-mannosidase activities were detected (table IV). Addition of $10 \mathrm{~mm}$ glucose to the mucin-containing medium decreased the levels of supernate and cell-associated glycosidases and the repression of glycosidase activities was most pronounced in cultures containing $50 \mathrm{~mm}$ glucose. Cells from cultures grown with glucose had specific activities $20 \%$ of those found in cells grown with mucin and

Table I. Optimal pH values of $S$. intermedius glycosidases

\begin{tabular}{l|ll}
\hline \multirow{2}{*}{ Enzyme } & \multicolumn{2}{|c}{$\mathrm{pH}$ value } \\
\cline { 2 - 3 } & Optimal & Range* \\
\hline$\beta$-D-galactosidase & $5 \cdot 5-6 \cdot 0$ & $5 \cdot 0-7 \cdot 2$ \\
N-acetyl- $\beta$-D-glucosaminidase & $5 \cdot 0-5 \cdot 5$ & $4 \cdot 5-6 \cdot 5$ \\
N-acetyl- $\beta$-D-galactosaminidase & $5 \cdot 0-5 \cdot 5$ & $4 \cdot 5-6 \cdot 5$ \\
Sialidase & $5 \cdot 5-6 \cdot 0$ & $4 \cdot 8-7 \cdot 1$ \\
\hline
\end{tabular}

* Range within which enzyme expressed $>50 \%$ of maximal activity.

Table II. Specific activities* of $S$. intermedius UNS35 glycosidases

\begin{tabular}{l|cc}
\hline Enzyme & $\begin{array}{c}\text { Activity with } \\
\text { pNp-linked } \\
\text { substrate }\end{array}$ & $\begin{array}{c}\text { Activity with } \\
\text { 4MU-linked } \\
\text { substrate }\end{array}$ \\
\hline$\beta$-D-galactosidase & 935 & 627 \\
N-acetyl-glucosaminidase & 569 & 414 \\
N-acetyl-galactosaminidase & 139 & 136 \\
Neuraminidase & $\ldots$ & 32 \\
$\alpha$-mannosidase & $<0 \cdot 1$ & $<0 \cdot 1$ \\
$\beta$-mannosidase & $<0 \cdot 1$ & $<0.1$
\end{tabular}

* Crude cell-free extracts were prepared from cultures of $S$. intermedius UNS35 grown on FAA. Chromogenic substrates and fluorogenic substrates were included in the assays at final concentrations of $1 \mathrm{~mm}$ and $0.5 \mathrm{~mm}$, respectively. Assays were performed at optimum $\mathrm{pH}$ and activities are expressed in units/mg of protein.

Table III. $\mathrm{k}_{\mathrm{m}}$ of glycosidases produced by $S$. intermedius

\begin{tabular}{l|cc}
\hline Enzyme & $\begin{array}{c}\mathrm{k}_{\mathrm{m}}(\mathrm{mM}) \text { with } \\
\mathrm{pNp} \text {-linked } \\
\text { substrate }\end{array}$ & $\begin{array}{c}\mathrm{k}_{\mathrm{m}} \text { (mM) with } \\
\text { 4MU-linked } \\
\text { substrate }\end{array}$ \\
\hline$\beta$-D-galactosidase & 1.56 & 0.17 \\
N-acetylglucosaminidase & 0.17 & 0.04 \\
N-acetylgalactosaminidase & 0.38 & 0.09 \\
Neuraminidase & - & 0.01
\end{tabular}

Chromogenic and fluorogenic substrates were included in the assays at concentrations up to $5.5 \mathrm{~mm}$. Data are shown for each enzyme at its optimum $\mathrm{pH}$ (figure). 
Table IV. Effect of glucose and mucin on the production of glycosidases by $S$. intermedius

\begin{tabular}{|c|c|c|c|c|c|}
\hline \multirow[b]{2}{*}{ Glycosidase } & \multicolumn{5}{|c|}{ Activity (units/mg of protein) after growth with } \\
\hline & Mucin & $\begin{array}{l}\text { Mucin } \\
+10 \mathrm{~mm} \\
\text { glucose }\end{array}$ & $\begin{array}{l}\text { Mucin } \\
+50 \mathrm{~mm} \\
\text { glucose }\end{array}$ & $\begin{array}{c}10 \mathrm{mM} \\
\text { glucose }\end{array}$ & $\begin{array}{l}50 \mathrm{~mm} \\
\text { glucose }\end{array}$ \\
\hline \multicolumn{6}{|l|}{ Sialidase } \\
\hline cell-associated & 42 & 8 & 1 & 14 & 3 \\
\hline supernate & 17 & 4 & $<1$ & $<1$ & 1 \\
\hline \multicolumn{6}{|l|}{$\beta$-D-galactosidase } \\
\hline cell-associated & 297 & 181 & 12 & 53 & 34 \\
\hline supernate & 186 & 43 & $<1$ & 1 & 6 \\
\hline \multicolumn{6}{|l|}{$\beta$-N-acetylglucosaminidase } \\
\hline cell-associated & 377 & 245 & 37 & 74 & 39 \\
\hline supernate & 228 & 47 & 3 & 22 & 19 \\
\hline \multicolumn{6}{|l|}{$\beta$-N-acetylgalactosaminidase } \\
\hline cell-associated & 214 & 106 & 11 & 42 & 41 \\
\hline supernate & 64 & 12 & 1 & 4 & 6 \\
\hline
\end{tabular}

Table V. PTS activities of cells of $S$. intermedius grown with glucose or mucin

\begin{tabular}{l|cc}
\hline $\begin{array}{l}\text { Monosaccharide } \\
\text { in assay }\end{array}$ & $\begin{array}{c}\text { Activity (nmol of NADH } \\
\text { oxidised/min/mg of protein) } \\
\text { after growth with }\end{array}$ \\
\cline { 2 - 3 } & glucose & mucin \\
\hline Glucose & 28.4 & 43.5 \\
N-acetylglucosamine & $25 \cdot 3$ & $40 \cdot 3$ \\
N-acetylgalactosamine & $<1$ & $<1$ \\
Fucose & $<1$ & $<1$ \\
Galactose & $<1$ & $3 \cdot 7$ \\
Mannose & 33.6 & $49 \cdot 1$ \\
Mannitol & $<1$ & $<1$ \\
\hline
\end{tabular}

glycosidic activities were significantly less in culture supernates from these cultures.

\section{Sugar PTS activities}

Cells of S. intermedius grown with glucose transported glucose, $\mathrm{N}$-acetylglucosamine and mannose at comparable rates (table $\mathrm{V}$ ) but $\mathrm{N}$-acetylgalactosamine, fucose and mannitol were not transported. Cells grown with mucin retained the ability to transport glucose, $\mathrm{N}$-acetylglucosamine and mannose at increased rates and additionally exhibited a low level of PTS activity for galactose.

\section{Neuraminate-pyruvate lyase activity}

The ability of $S$. intermedius to utilise N-acetylneuraminate was investigated indirectly by determining the level of intracellular neuraminate-pyruvate lyase. No significant activity $(<1 \mathrm{nmol} / \mathrm{min} / \mathrm{mg}$ ) was detected in cell-free extracts of cells grown with glucose but considerable activity $(93 \mathrm{nmol}$ of NADH oxidised $/ \mathrm{min} / \mathrm{mg}$ of protein) was detectable in cells grown with mucin.

\section{Discussion}

$S$. intermedius strain UNS35 produced $\beta$-D-galactosidase, $\mathrm{N}$-acetyl- $\beta$-D-glucosaminidase, $\mathrm{N}$-acetyl- $\beta$-Dgalactosaminidase and neuraminidase (sialidase) but not $\alpha$-or $\beta$-mannosidase. Studies with oral streptococci have indicated that the ability to elaborate these activities, determined with synthetic substrates, was a measure of the ability of these bacteria to degrade oligosaccharide side chains of native glycoproteins. ${ }^{12,13,18-20}$ Therefore, such activities should provide $S$. intermedius with sufficient metabolic capability to degrade the greater proportion of the external portions of oligosaccharide side-chains of glycoproteins. Many of the host-derived glycoproteins likely to be encountered by $S$. intermedius in vivo are of the "mucin-type", in which the oligosaccharide chains are conjugated via O-glycosidic linkage to a serine or threonine residue of the protein backbone. ${ }^{21}$ Among the principle monosaccharides of these glycans are sialic acid, galactose, $\mathrm{N}$-acetylglucosamine and $\mathrm{N}$ acetylgalactosamine. The range of exoglycosidic enzymes investigated here was chosen to reflect the composition of these molecules.

The optimal $\mathrm{pH}$ values of these enzymes were below neutrality ( $\mathrm{pH} 5 \cdot 0-6 \cdot 0$ ), but each was active over a wide $\mathrm{pH}$ range. This may be advantageous in vivo, ensuring the ability to degrade host tissue components in a range of environmental conditions, ranging from deep-seated purulent abscesses to the healthy tooth surface. The $\mathrm{k}_{\mathrm{m}}$ of these enzymes varied according to the type of substrate used. Of interest is the low $\mathrm{k}_{\mathrm{m}}$, and therefore high affinity, of the sialidase for its substrate. The $\mathrm{k}_{\mathrm{m}}$ for the $S$. intermedius sialidase is lower than that reported for the enzyme from Vibrio cholerae, Clostridium perfringens or Arthrobacter ureafasciens. ${ }^{21}$ This enzyme has been implicated as a bacterial virulence determinant for a number of species including $V$. cholerae and Bacteroides fragilis. ${ }^{22,23}$ The high affinity of the sialidase for the substrate is 
important because of the role of sialic acids in a range of essential cell functions and because sialic acids always occupy terminal positions on oligosaccharide sidechains. Their removal is a primary event in glycoprotein deglycosylation. ${ }^{24}$

Porcine gastric mucin has been used previously as a model glycoprotein because of its marked structural similarity to certain human glycoproteins. When grown in minimal medium supplemented with mucin as a sole source of fermentable carbohydrate, significantly raised levels of $\beta$-D-galactosidase, $\mathrm{N}$-acetyl$\beta$-D-glucosaminidase, $\mathrm{N}$-acetyl- $\beta$-D-galactosaminidase and neuraminidase were expressed by $S$. intermedius. Glucose markedly repressed these glycosidic activities. Therefore, it is likely that, in vivo, where levels of free fermentable carbohydrate are low, these glycosidic enzymes may be fully derepressed. The expression of these activities within tissues would facilitate bacterial survival in the way suggested for $S$. oralis associated with septicaemia in neutropenic cancer patients. ${ }^{25}$

The ability of bacteria to attach to host tissue ${ }^{26}$ and to produce enzyme activities with the potential to liberate monosaccharides from glycoproteins is unlikely, alone, to be sufficient to ensure abscess formation. The bacteria must also be able to utilise liberated host-tissue components. Therefore, the ability of $S$. intermedius, grown with glucose and mucin, to transport via PTS systems the principal carbohydrates of oligosaccharide sidechains was also studied. Cultures grown with glucose exhibited PTS activities for glucose, $\mathrm{N}$-acetylglucosamine and mannose, as reported

\section{References}

1. Gossling J. Occurrence and pathogenicity of the Streptococcus milleri group. Rev Infect Dis 1988; 10: 257-285.

2. Piscitelli SC, Shwed J, Schreckenberger P, Danziger LH Streptococcus milleri group: renewed interest in an elusive pathogen. Eur J Clin Microbiol Infect Dis 1992; 11: 491-498.

3. Poole PM, Wilson G. Occurrence and cultural features of Streptococcus milleri in various body sites. J Clin Pathol 1979; 32: 764-768.

4. Ruoff KL. Streptococcus anginosus ("Streptococcus milleri"): the unrecognized pathogen. Clin Microbiol Rev 1988; 1: 102-108.

5. Whiley RA, Beighton D. Emended descriptions and recognition of Streptococcus constellatus, Streptococcus intermedius, and Streptococcus anginosus as distinct species. Int $J$ Syst Bacteriol 1992; 41: 1-5.

6. Whiley RA, Beighton D, Winstanley TG, Fraser HY, Hardie JM. Streptococcus intermedius, Streptococcus constellatus and Streptococcus anginosus (the Streptococcus milleri group): association with different body sites and clinical infections. J Clin Microbiol 1992; 30: 243-244.

7. Whiley RA, Fraser H, Hardie JM, Beighton D. Phenotypic differentiation of Streptococcus intermedius, Streptococcus constellatus, and Streptococcus anginosus strains within the "Streptococcus milleri group". J Clin Microbiol 1990; 28 1497-1501.

8. Homer KA, Denbow L, Whiley RA, Beighton D. Chondroitin sulfate depolymerase and hyaluronidase activities of viridans streptococci determined by a sensitive spectrophotometric assay. J Clin Microbiol 1993; 31 : 1648-1651.

9. Ruoff KL, Ferraro MJ. Hydrolytic enzymes of "Streptococcus milleri". J Clin Microbiol 1987; 25: 1645-1647.

10. Unsworth PF. Hyaluronidase production in Streptococcus milleri in relation to infection. $J$ Clin Pathol $1989 ; 42$ $506-510$. previously for $S$. mutans and S. sobrinus. ${ }^{16} \mathrm{~N}$-acetylglucosamine, mannose and glucose are probably taken up by a common PTS system. ${ }^{27}$ Cells grown with mucin transported these sugars at elevated rates and, in addition, exhibited low PTS activity with galactose, as has been reported with lactobacilli. ${ }^{27,28}$ The possibility that galactose may also be transported via transport mechanisms other than the PTS was not investigated in this study.

Growth of $S$. intermedius in the presence of mucin induced neuraminate-pyruvate lyase activity. Direct transport of sialic acid into $S$. intermedius cells was not measured, but sialic acid is transported via specific permeases which are independent of phosphoenolpyruvate in other genera. ${ }^{29}$ However, neuraminatepyruvate lyase initiates the catabolism of neuraminate to pyruvate and $\mathrm{N}$-acetylmannosamine. The pattern of induction of this enzyme in S. intermedius has also been reported for Escherichia coli, in which neuraminate-pyruvate lyase activity is induced only during growth on a sialic acid-containing substrate. ${ }^{30,31}$

These data indicate that $S$. intermedius grown with mucin exhibits increased levels of glycosidase activities and also the ability to transport simultaneously, and potentially utilise, the principal carbohydrate moieties of glycoprotein oligosaccharide side chains. These abilities might confer an advantage in vivo and contribute to the ability of $S$. intermedius to grow at sites anatomically removed from its normal habitat, the oral cavity.

11. Beighton D, Hardie JM, Whiley RA. A scheme for the identification of viridans streptococci. $J$ Med Microbiol 1991; 35: 367-372.

12. van der Hoeven JS, van den Kieboom CWA, Camp PJM. Utilization of mucin by oral Streptococcus species. Antonie Van Leeuwenhoek 1990; 57: 165-172.

13. Beighton D, Smith K, Glenister DA, Salamon K, Keevil CW. Increased degradative enzyme production by dental plaque bacteria in mucin-limited continuous culture. Microb Ecol Hlth Dis 1988; 1 : 85-94.

14. Bradshaw DJ, McKee AS, Marsh PD. Effects of carbohydrate pulses and $\mathrm{pH}$ on population shifts within oral microbial communities in vitro. J Dent Res 1989 ; 68: 1298-1302.

15. Russell RRB. Comparison of oral Streptococcus mutans AHT with strains of serotypes $a$ and $g$ by biochemical and electrophoretic methods. Arch Oral Biol 1979; 24: 617-619.

16. Homer KA, Patel R, Beighton D. Effects of N-acetylglucosamine on carbohydrate fermentation by Streptococcus mutans NCTC 10449 and Streptococcus sobrinus SL-1. Infect Immun 1993; 61 : 295-302.

17. Slee AM, Tanzer JM. Phosphoenolpyruvate-dependent sucrose phosphotransferase activity in Streptococcus mutans NCTC 10449. Infect Immun 1979; 24: 821-828.

18. de Jong $\mathbf{M H}$, van der Hoeven JS. The growth of oral bacteria on saliva. J Dent Res 1986; 66: 498-505.

19. Beighton D, Smith K, Hayday $H$. The growth of bacteria and the production of exoglycosidic enzymes in the dental plaque of macaque monkeys. Arch Oral Biol 1986; 31 : 829-835.

20. Beighton $\mathrm{D}$, Smith $\mathrm{K}$. The modulation of exoglycosidic enzymes in the supragingival plaque of macaque monkeys. FEMS Microbiol Lett 1986; 34: 319-322.

21. Montreuil J, Bouquelet S, Debray H, Fournet B, Spik G, Strecker G. Glycoproteins. In: Chaplin MF, Kennedy JF (eds) Carbohydrate analysis: a practical approach. Oxford, IRL Press. 1986: 143-204. 
22. Russo TA, Thompson JS, Godoy VG, Malany MH. Cloning and expression of the Bacteroides fragilis TAL 2480 neuraminidase gene, nan $\mathrm{H}$, in Escherichia coli. $J$ Bacteriol $1990 ; 172: 2594-2600$.

23. Vimr ER, Lawrisuk L, Galen J, Kaper JB. Cloning and expression of Vibrio cholerae neuraminidase gene nanH in Escherichia coli. J Bacteriol 1988; 170: 1495-1504.

24. Schauer R. Sialic acids and their role as biological masks. Trends Biochem Sci 1985; 10: 357-360.

25. Beighton D, Carr AD, Oppenheim BA. Identification of viridans streptococci associated with bacteraemia in neutropenic cancer patients. J Med Microbiol 1994; 40: 202-204.

26. Reid G, Bruce AW, McGroarty JA, Cheng K-J, Costerton JW. Is there a role for lactobacilli in prevention of urogenital and intestinal infections? Clin Microbiol Rev 1990; 3: 335-344.

27. Postma PW, Lengeler JW. Phosphoenolpyruvate : carbohydrate phosphotransferase system of bacteria. Microbiol Rev 1985; 49: 232-269.

28. Chassy BM, Thompson J. Regulation and characterization of the galactose-phosphoenolpyruvate-dependent phosphotransferase system in Lactobacillus casei. $J$ Bacteriol 1983; 154: $1204-1214$

29. Rodríguez-Aparicio LB, Reglero A, Luengo JM. Uptake of Nacetylneuraminic acid by Escherichia coli K-235. Biochemical characterization of the transport system. Biochem $J$ 1987; 246 : 287-294.

30. Aisaka K, Igarashi K, Yamaguchi K, Uwajima T. Purification, crystallization and characterization of $\mathrm{N}$-acetylneuraminate lyase from Escherichia coli. Biochem J 1991; 276: 541-546.

31. Schauer R. Chemistry, metabolism, and biological functions of sialic acids. Adv Carbohydr Chem Biochem 1982; 40: 131-234. 